\title{
Anticancer Activity of Euonymus europaeus Fruit Extract on Transplantable Mouse Tumor Model
}

\author{
Orsolya SÁRPATAKI ${ }^{1}$, Roxana L. STAN ${ }^{2}$, Adriana C. HANGAN ${ }^{2}$, Neli K. OLAH ${ }^{3,4}$, Alexandra C. SEVASTRE- \\ BERGHIAN $^{2}$, Daniela BENEDEC ${ }^{2}$, Daniela HANGANU ${ }^{2}$, Bogdan SEVASTRE ${ }^{1 *}$, Ioan MARCUS ${ }^{1}$ \\ ${ }^{1}$ University of Agricultural Science and Veterinary Medicine, Faculty of Veterinary Medicine, Manastur \\ Street. 3-5, 400372, Cluj-Napoca, Romania \\ ${ }^{2}$ University of Medicine and Pharmacy "Iuliu Hateganu", Emil Isaac Street 13, 400023, Cluj-Napoca, \\ Romania \\ 3 "Vasile Goldis” West University of Arad, Feleacului Street 1, 300041, Romania \\ ${ }^{4}$ PlantExtrakt Ltd, 407059 Rădaia, Cluj-Napoca, Romania \\ * Corresponding author: bogdan.sevastre@usamvcluj.ro
}

Bulletin UASVM Veterinary Medicine 73(1) / 2016,

Print ISSN 1843-5270; Electronic ISSN 1843-5378

DOI:10.15835/buasvmcn-vm: 11946

\begin{abstract}
Euonymus europaeus L. (EE), is the only European representant of the Celastraceae family, with limited use in phytotherapy. In the present study, we investigated the anticancer effects of EE hydro alcoholic extract prepared from fresh fruits. HPLC analysis revealed the presence of evodiamine in concentration of $0.404 \mathrm{~g} / \mathrm{ml}$. Antitumor effect was assessed in vivo on Swiss mice. Mice implanted with transplantable tumor cells were treated with 25 or $50 \mathrm{mg} / \mathrm{kg}$ EE extract, by IP injection on the $1^{\text {st }}, 3^{\text {rd }}$ and $6^{\text {th }}$ day, the study lasted for 14 days long. A parallel study assesses the median survival rate. EE therapy, at the higher dose, prevented the body weight gain $(\mathrm{p}<0.001)$, reduced the volume of ascitic fluid by $71.88 \%(p<0.001)$ and increased the median survival rate by $28.57 \%$ $(\mathrm{p}<0.05)$.
\end{abstract}

Keywords: antitumor, Ehrlich ascites carcinoma, evodiamine, medicinal plants

\section{INTRODUCTION}

Research for new anticancer drugs is a very active domain, as long as natural products represent an important source of new drugs. Nowadays, more than $60 \%$ of the new therapeutic compounds are either isolated from natural products, or incorporate themselves synthetic compounds, which have similar chemical structure of some natural products (Chabner and Roberts, 2005).

Plants from the Celastraceae family have been used for centuries in traditional medicine, in South America, China, and Africa (Descoins et al., 2002). Of all, Euonymus alatus (Thunb) Celastraceae (EA), a species native to Southeastern Asia, is commonly recommended as medicinal plant, inclusive in cancer treatment $(\mathrm{Xu}, 2015)$. Various authors described several pathways responsible for its remarkable anticancer properties; two of them are of main importance. According to Kim et al. (2006), it exhibits antitumor properties by inducing apoptosis via mitochondrial pathway. Other authors showed that EA inhibits tumor invasion, mainly by suppression of the matrix metalloproteinase-9 (MMP-9) activity (Cha et al. 2003, Jin et al. 2005), effect provided by dihydroxycinnamic acid (caffeic acid) (Park et al., 2005). The inhibition of MMP-2 and MMP-9 seems to be mediated by NK-kappaB pathway (Chung et al., 2004).

Euonymus europaeus L., (EE) known also as the spindle tree, is the only European represen- 
tative of the Celastraceae family. It is a small deciduous tree with poisonous fruits, with very limited use in phytotherapy until now. Few phytochemical analysis performed on EE revealed some active compounds including sesquiterpene polyesters belonging to the alatol, 3-deoxymatol, 3,4-dideoxymaytol families, evonimate alkaloids, dihydro-ß-agarofuran polyesters (Descoins et al., 2002), and lectins (Teneberg et al., 2003) with erythrocyte agglutination properties (Agostino et al. 2015).

The aim of the present study is to investigate the anticancer activity of EE alcoholic extract using a transplantable tumor models in vivo.

\section{MATERIALS AND METHODS}

\section{Plant materials and extraction}

Fresh fruits of EE, harvested in September 2011, from the forests near Cluj, Romania, were used to prepare the hydro alcoholic extract. The collecting of fruits was performed according to the GACP rules, from an unpolluted area, at a minimum of $3 \mathrm{~km}$ distance from any circulated roads. The fruits were identified by the Quality Control laboratory of PlantExtrakt TC Ltd, Rădaia, Cluj County, Romania. A voucher specimen was filed and kept in the company archives (B. no. 063811, CoA 4817/20.09.2011).

The moisture in the fresh vegetal material is $70 \%$., as described in previous studies (Sevastre et al., 2014). Briefly, the freshly cut vegetal material was mixed with $90 \%$ vol. ethanol, at 1:0.7 ratio. The mixture was kept at room temperature for ten days long, and then, the mixture was pressed and filtered. All steps were performed on an APIGMP certified production flow at SC Plant Extrakt SRL in Rădaia, Cluj County, Romania, according to method 2a from the German Homoeopathic Pharmacopoeia.

Before use, the alcoholic solution was processed in a rotary evaporator at $40^{\circ} \mathrm{C}$, until $3 / 4$ of the content was evaporated, then refilled with sterile saline solution up to $0.5 \mathrm{ml} /$ animal. The aqueous solution was sterilized by transferring throughout syringe filters, and was immediately administered. The control group received a placebo, $0.5 \mathrm{ml}$ alcohol $70^{\circ}$, previously evaporated, similarly to the plant extract method.

\section{Standardization of mother tincture}

The standardization procedures were already presented in previous studies (Sevastre et al.,
2014), however the methods were being briefly described in the paragraphs below.

\section{Determination of aspect, relative density, dry residue and ethanol content}

The countenance, color and smell of mother tincture was determined by observation, additionally relative density, dry residue and the ethanol content were determined

\section{Thin-layer chromatography (TLC)}

The Thin-layer chromatography (TLC) determination was performed according to the German Homeopathic Pharmacopoeia. $10 \mathrm{ml}$ of EE extract was mixed for five minutes with $20 \mathrm{ml}$ water and $10 \mathrm{ml} 9.5 \%$ lead acetate. The extraction was made with $2 \times 15 \mathrm{ml}$ mixture of chloroform - iso-propanol $(3: 2, v / v)$. The organic phase was separated and dried at maximum $50^{\circ} \mathrm{C}$. The dry residue was dissolved in $0.5 \mathrm{ml}$ methanol. $40 \mu \mathrm{l}$ of prepared sample and $20 \mu \mathrm{l}$ of standard solutions, respectively, were applied on TLC plate. The TLC determination was performed on Silicagel F254 plates, using as mobile phase a mixture of ethyl acetate, methanol and water $(81: 11: 8, \mathrm{v} / \mathrm{v})$. Digitoxin $0.5 \mathrm{mg} / \mathrm{ml}$ and lanatosid C $0.5 \mathrm{mg} /$ $\mathrm{ml}$, respectively, were used as standards. The evaluation of the plate was made after spraying it with a mixture of $3 \%$ trichloramine $\mathrm{T}$ and $25 \%$ trichloracetic acid $(2: 8, \mathrm{v} / \mathrm{v})$, exposing it to heating for $5-10$ minutes, at $105-110^{\circ} \mathrm{C}$ and visualizing it afterwards in fluorescence at $365 \mathrm{~nm}$.

\section{Determination of evodiamine content}

The evodiamine content was determined by HPLC, using a method provided by Phytolab and adapted in the view of getting a better separation of compounds from mother tincture, as a start. The determination was performed using a Varian ProStar HPLC system. A Phenomenex Luna C18 silicagel-C18 column was used, $150 \mathrm{~mm} \times 4.6 \mu \mathrm{m}$ with a precolumn of $5 \mathrm{~mm} \times 4.6 \mu \mathrm{m}$, both having particles of $5 \mu \mathrm{m}$. As a mobile phase, a solvent gradient with phosphoric acid $\mathrm{pH}=2.5$, water and acetonitrile, with a $1 \mathrm{ml} / \mathrm{min}$ flow rate were used. The detection was performed with a DAD detector at $228 \mathrm{~nm}$. The UV-Vis spectra were recorded from $200 \mathrm{~nm}$ to $600 \mathrm{~nm}$.

Volumes of $100 \mu \mathrm{l}$ of EE extract from each concentration of standard evodiamine solution were injected. For the quantitative determination, a calibration curve with concentrations of evodiamine ranging between $50 \mu \mathrm{g} / \mathrm{ml}$ and 500 $\mu \mathrm{g} / \mathrm{ml}$ was built. The calibration curve's equation 
is $\mathrm{A}=60110 \mathrm{xC}-478977$ and the correlation factor is 0.9807 . The identification was made based on the comparison between the retention time and UV-Vis spectra of compounds separated from EE extract and the standard evodiamine. The absorption maximum of evodiamine is at $228 \mathrm{~nm}$.

\section{Animal care and experimental procedures}

The experiments on animals were performed according to the Directive 2010/63/EU of the European Parliament and of the Council and Low no. 43/11.04.2014 of the Romanian Parliament, following the guidelines of Guide for the Care and Use of Laboratory Animals (Department of Health Education, and Welfare, National Institute of Health, 1996). The Bioethical Board of the Faculty of Veterinary Medicine, Cluj-Napoca, authorized the experiment. The animals were housed in polycarbonate cages, at a controlled temperature $\left(21-22^{\circ} \mathrm{C}\right)$, humidity (40-60\%) and $12 / 12 \mathrm{~h}$ light/dark cycle. Standard lab chow, provided by National Institute for Research and Development Cantacuzino Bucharest, and water were freely available. Albino Swiss female mice were used in these experiments, having a body weight about $33.75 \pm 3.52 \mathrm{~g}$.

In the present study, we performed two independent experiments: the first one was designed to assess the antiproliferative effect of the extract and the ability to reduce the side effect of tumor growth, while the second one was dedicated to survival analysis.

For the first experiment, the animals were organized in three equal groups of eight mice, and treated as follow:

I. - mice implanted with Ehrlich ascites carcinoma (EAC) cells, $10^{6}$ ascitic cells each, on day 0 , and placebo intraperitoneally;

II. - EAC implanted mice, receiving $50 \mathrm{mg} / \mathrm{kg}$ b.w.; EE extract, IP

III. - EAC implanted mice, receiving $25 \mathrm{mg} / \mathrm{kg}$ b.w EE extract,. IP;

All animals received the EE ethanolic extract on the $1^{\text {st }}, 3^{\text {rd }}$ and $6^{\text {th }}$ day. The body weight was measured on a daily basis, until the end of the study.

Ehrlich ascitic fluid was implanted $\left(10^{6}\right.$ tumor cells/mouse), on day 0 of the experiment. Fourteen days after EAC implantation, blood was collected from the retro orbital sinus under anesthesia and the animal were subsequently euthanized.
Complete blood count (CBC) was performed using Abacus Junior Vet, automatic analyzer (Diatron Messtechnik, Budapest, Hungary).

The volume of ascitic fluid was measured with a syringe, and then transferred in a phosphate buffer solution $\left(4^{\circ} \mathrm{C}, \mathrm{pH} 7.4\right)$. The cell viability was assessed by Tripan blue staining $(0.4 \%$ in PBS), the total and viable tumor cell concentration was counted by using a hemocytometer (dilution 1:10). Smears were made from peritoneal fluid and stained by Dia Quick Panoptic method. The cells were then differentiated on a 100x field objective, by an observer unaware of the experimental design. The cells were differentiated into tumor cells, neutrophils, macrophages, lymphocytes using classic morphological patterns, counting 200 cells for each sample, based on classical morphological criteria (Jain, 1993).

For the second experiment, we use only the higher dose of E. europaeus $(50 \mathrm{mg} / \mathrm{kg})$. Sixteen animals were organized in two equal groups: both implanted with Ehrlich ascites carcinoma (EAC) cells, one group was treated and the other one not. In this study we performed two experiments: one in which the animals were allowed to live for 2 weeks long and then euthanized to assess the amount of ascitic fluid and cellular content of ascitic fluid (all of them survived to the end of 2 weeks), and the second experiment in which the animals were not killed but observed until the day they die, by a survival test. The results were then analyzed by Long Rank test and survival curves were generated.

\section{Statistical analysis}

All data are reported as the mean \pm SEM. The Gaussian distribution was checked by the Shapiro-Wilk normality test. One-way analysis of variance ANOVA, followed by post hoc Dunnett's range test procedure was performed for pair-wise comparisons between the volume of ascitic fluid and variation of viable cells concentration, while the two-way ANOVA followed by the Bonferroni post-test was the choice for the variation of body weight. Pearson's correlation was used in order to assess the correlation between normally distributed variables; this interpretation was made according to the Colton scale. Statistical significance was at $\mathrm{p}<0.05 \quad(95 \%$ confidence interval). The comparison between survival curves was evaluated throughout Long-rank (Mantel-Cox) Test. Statistical values and figures were obtained 
using GraphPad Prism version 5.0 for Windows, GraphPad Software, San Diego California USA.

\section{RESULTS AND DISCUSSION}

Standardization of the studied mother tincture

The obtained hydro alcoholic extract (mother tincture) was a clear, brown-orange liquid. The quality parameters of the extract were within the admissibility range of German Homeopathic Pharmacopoeia. TLC chromatogram of the EE extract showed the presence of lanatoside $\mathrm{C}$, a cardiotonic glycoside. Hence, only insignificant amount of digitoxin was also found. HPLC chromatogram revealed the presence of evodiamine in concentration of $0.404 \mathrm{~g} / \mathrm{ml}$, while the recorded UV-vis spectra further proved the presence of evodiamine in the extract (Sevastre et al., 2014)

\section{Antiproliferative effect in vivo}

In EAC inoculated mice, the WBCs count was four times over the normal maximum range. The blood leukocytosis was mainly based on neutrophilia $(\mathrm{p}<0.001)$, but the lymphocytes number was also significantly increased $(\mathrm{p}<0.001)$. A significant decrease in WBCs count was observed in mice treated with EE alcoholic extract, both neutrophils and lymphocytes being influenced (Tab. 1.).

The blood neutrophils were positively correlated with the lymphocytes $(\mathrm{r}=0.55, \mathrm{p}<0.01)$, but not with other leucocytes. Neutrophils also showed a good positive correlation with fibrin content of the ascitic fluid $(\mathrm{r}=0.52, \mathrm{p}<0.05)$ and congestion of the abdominal wall $(r=0.43, p<0.05)$. There was also a positive correlation between the number of neutrophils and the medium platelet volume $(r=0.63, p<0.01)$, which suggested a common inflammatory mechanism beneath these two hematological changes.
The body weight, as a measure of Ehrlich ascites accumulation in the peritoneal cavity is shown in figure 1. As expected, the ascites development was followed by $32.90 \pm 7.98 \%$ increase in the body weight. The EE therapy prevents body weight gain. The differences were visible starting from the third day of the study: both doses proved to provide significant protection, but the effect was more visible in the group treated with the higher dose.

The amount of ascitic fluid varied proportionally with the body weight gain. $50 \mathrm{mg} / \mathrm{kg}$ EE administered reduced by $71.88 \%$ the medium volume of ascites fluid, but the lower dose $(25 \mathrm{mg} /$ $\mathrm{kg}$ ) was also effective; it reduced the accumulation of ascitic fluid by up to $39.06 \%$ (EAC $10.67 \pm 2.42$ $\mathrm{ml}, \mathrm{EAC}+50 \mathrm{mg} / \mathrm{kg} 3.06 \pm 0.75 \mathrm{ml}, \mathrm{EAC}+25 \mathrm{mg} / \mathrm{kg}$ $6.50 \pm 1.44 \mathrm{ml}, \mathrm{p}<0.05$ ) (Fig $2 \mathrm{~A}$ ).

The total viable tumor cell concentration in the peritoneal fluid significantly decreased in the groups treated with EE. The extract administered in dose of $50 \mathrm{mg} / \mathrm{kg}$ and $25 \mathrm{mg} / \mathrm{kg}$ reduced the tumor cell concentration by up to $67.93 \%$ and $66.30 \%$ (p<0.01) (Fig. 2 B).

The correlation test showed a positive correlation between the percentage of body weight gain and the amount of ascitic fluid ( $\mathrm{r}=0.54 \mathrm{p}<0.05)$, but no relation between the amount of ascitic fluid and the tumor cell concentration could be proven $(\mathrm{r}=-0.044, \mathrm{p}=0.89$ ). Furthermore, the cellularity of the ascitic fluid was positively correlated with the blood neutrophils count $(r=0.803, p<0.01)$, but again, no correlation with the ascitic volume could be proven $(\mathrm{r}=0.12, \mathrm{p}=0.72)$.

The evaluation of ascitic hemorrhage showed that EE therapy provided some protection, but the semiquantitive analysis showed no statistically significant data. The hemorrhagic aspect of the ascitic fluid is due to extensive leaking of red

Tab. 1. The effect of E. europaeus alcoholic extract on the WBC count and differential count (mean \pm S.E.M.) $\left(10^{9}\right.$ cells $/$ L)

\begin{tabular}{|c|c|c|c|c|c|c|}
\hline Group & WBCs & $\mathbf{N}$ & $\mathbf{E}$ & B & $\mathbf{L}$ & $\mathbf{M}$ \\
\hline I & $46.79 \pm 2.05$ & $31.72 \pm 2.82$ & $0.30 \pm 0.14$ & $0.07 \pm 0.06$ & $12.81 \pm 1.96$ & $1.88 \pm 0.34$ \\
\hline II & $11.59 \pm 2.40^{* * *}$ & $6.04 \pm 1.39 * * *$ & $1.00 \pm 0.68$ & $0.01 \pm 0.01$ & $2.84 \pm 0.43^{* * *}$ & $1.69 \pm 0.59$ \\
\hline III & $19.58 \pm 2.39 * * *$ & $12.73 \pm 1.53^{* * *}$ & $0.31 \pm 0.09$ & $0.06 \pm 0.04$ & $5.19 \pm 0.68^{* *}$ & $1.29 \pm 0.20$ \\
\hline $\begin{array}{l}C^{* *}=\mathrm{p}>0.0 \\
\text { S.E.M }=\text { Sta } \\
\text { WBCs - Wh } \\
\text { Normal val } \\
10^{3} \text { cells } / \mu l\end{array}$ & $\begin{array}{l}\text { itard Error of the M } \\
\text { ite blood cells, } \mathrm{N}-\mathrm{N} \\
\text { ies: WBC } 2.61-10.05 \\
\text { B } 0-0.0210^{3} \text { cells } / \mu l\end{array}$ & $\begin{array}{l}\text { mpared to EAC group } \\
\text { an (8 animals / grou } \\
\text { utrophils, E - Eosino } \\
10^{3} \text { cells/ } \mu \mathrm{l}, \mathrm{N} 0.4-2.0 \\
\text { Jain, } 1993 \text { ) }\end{array}$ & $\begin{array}{l}\text { p) } \\
\text { phils, B - Basor } \\
10^{3} \text { cells/ } \mu \mathrm{l}, \mathrm{L} 1\end{array}$ & $\begin{array}{l}\text { iles, L - Lym } \\
7-8.4410^{9} /\end{array}$ & $\begin{array}{l}\text { ocytes, M - Mon } \\
0-0.2910^{3} \text { cells }\end{array}$ & $\begin{array}{l}\text { ytes } \\
\text { l, E 0-0.17 }\end{array}$ \\
\hline
\end{tabular}


blood cells into the peritoneal cavity and it is a malignant side effect of EAC development (Mayer, 1966). Many ascitic samples rich in red blood cells also showed a high fibrin content, probably also related to the increased vascular permeability in the abdominal wall capillaries. The vascular changes of the abdominal wall were less evident in groups subjected to therapy, but the differences were not statistically sustained.

The percentage of white blood cells in the ascitic fluid was several times higher in EE treated mice, while the tumor cell percentage decreased. Neutrophils were the most prevalent category, but lymphocytes were also found (tab. 2). These findings suggest that the inflammatory cells in the ascitic fluid provided some protection against ascites development, while blood leucocytes did not. The correlation test confirms this observation, while ascitic lymphocytes showed a negative correlation with fibrin content in the ascitic fluid $(\mathrm{r}=-0.52, \mathrm{p}<0.05)$ and congestion of the abdominal wall $(\mathrm{r}=0.51, \mathrm{p}<0.05)$; neutrophils found in the ascitic fluid were also negatively correlated with these two parameters.

Blood neutrophilic leukocytosis is a side effect of tumor cell proliferation in response to tumor inflammatory cytokines (Liao et al., 2005, Sarpataki et al., 2011), but the efficiency of this reactive response seems to be limited because the circulating inflammatory cells fail to pass through capillary walls and migrate into the peritoneal fluid. Consequently, the ascitic fluid in control EAC implanted mice is rich in tumor cells, but the inflammatory cells are sparsely distributed. As a result of therapy, the number of tumor cells decreased, but the percentage of inflammatory cells in the ascitic fluid was elevated, in inverse correlation with the circulating blood leukocytes.

The EE anticancer effect was further proved within the survival experiment carried out. The therapy increased by $28.57 \%$ the median survival of EAC-bearing mice (EAC median, 14 days, EAC + EE 50 mg/kg b.w., 18 days; p<0.05) (Fig 3).

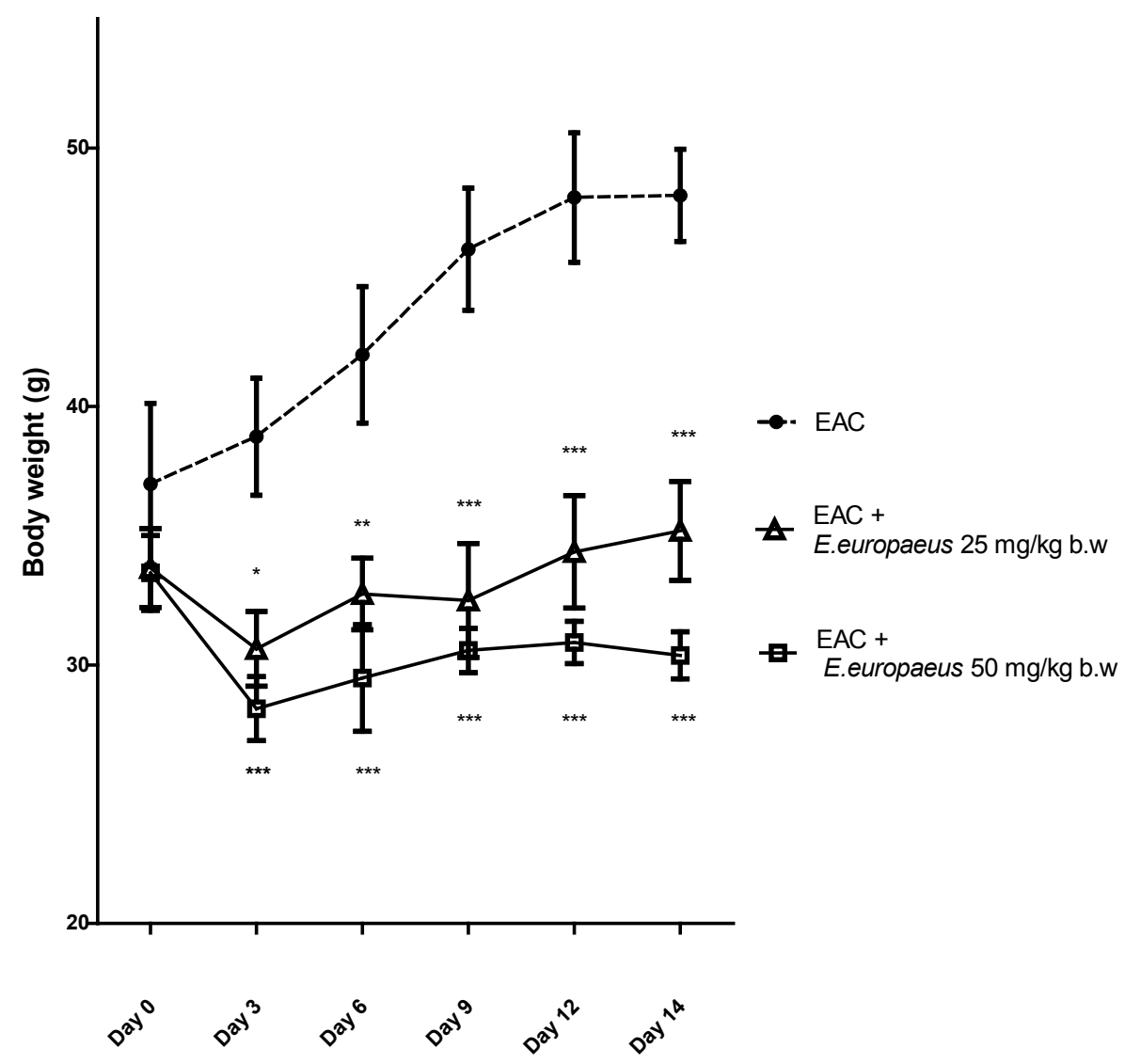

Fig. 1. Effects of Euonymus europaeus extract on the body weight gain (g) $C^{*}=\mathrm{p}>0.05:{ }^{* *}=\mathrm{p}>0.01 ;{ }^{* * *}=\mathrm{p}>0.001$ as compared to EAC group $)$. (mean \pm SEM) (8 animals / group) 
Initially, phytochemical investigation searched for phytotherapeutic compounds already known to be found in the EE extract, such as cardiac glycosides as digitoxin and lanatoside c. However, cardiac glucosides alone seems to be unable to explain this potent anticancer effect on their own, thus, we searched for more compounds, and, eventually, evodiamine was found.

In vivo studies were performed on a classic transplantable tumor model - Ehrlich ascites carcinoma inoculated in mice. This study provided valuable information regarding the antiproliferative potential of the EE extract, but they also implied important limitations related to kinetics, bioavailability, tissue distribution, route of systemic circulation, catabolism and secretion. Therefore, we consider that further studies need to be carried out in order to establish its applicative

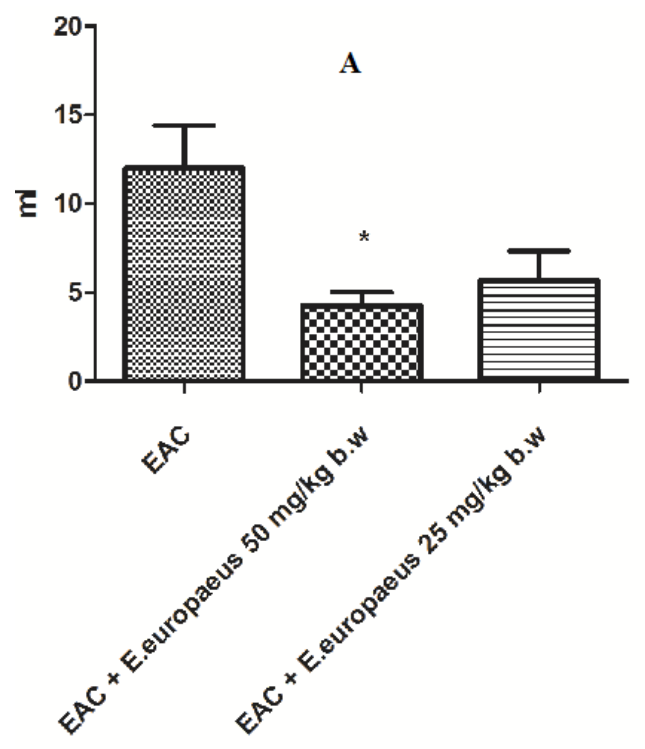

value in finding new molecules that can be used in cancer therapy.

Little is known about the pharmacological properties of E. europaeus, but several studies found various active compounds in this plant, some of them with possible anticancer effect, like sesquiterpenes, alkaloids (Descoins et al., 2002), lectins (Teneberg et al., 2003). On the other hand, the other members of Euonymus species ex Ealatus have well documented anticancer properties. An antiproliferative mechanism was proposed for mammary and genital tumors, respectively the inhibition of aromatase activity. Aromatase or estrogen synthetase is an enzyme responsible for estrogen synthesis. A large proportion of breast cancer expresses their own aromatase; therefore, the cell proliferation is enhanced by an autocrine stimulating mechanism. E alatus was highly effective in inhibiting the intracellular aromatase

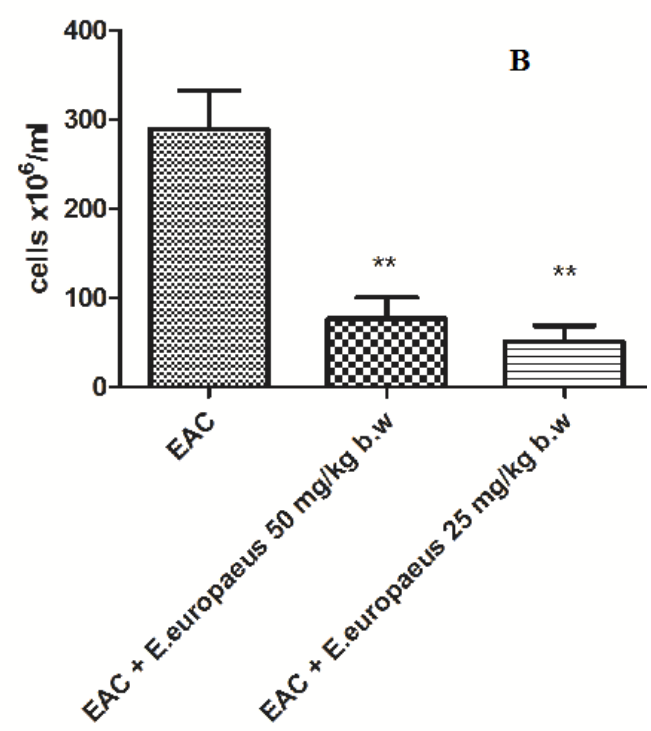

Fig. 2. Effects of Euonymus europaeus extract on ascitic fluid accumulation (ml) (A) and viable Ehrlich tumor cells concentration (B).

$C^{*}=\mathrm{p}>0.05::^{* *}=\mathrm{p}>0.01 ;$ as compared to EAC group). (mean \pm SEM) (8 animals $/$ group)

Tab. 2. The effect of E. europaeus alcoholic extract on the cytology of the peritoneal fluid (mean \pm S.E.M.) (\%)

\begin{tabular}{cccccc}
\hline Group & EAC cells & $\mathrm{N}$ & $\mathrm{E}$ & $\mathrm{L}$ & $\mathrm{M}$ \\
\hline $\mathrm{I}$ & $65.00 \pm 8.44$ & $23.25 \pm 06.26$ & $0.00 \pm 0.00$ & $11.75 \pm 03.57$ & $0.00 \pm 0.00$ \\
\hline II & $28.50 \pm 9.58$ & $45.50 \pm 011.44$ & $0.33 \pm 0.21$ & $25.50 \pm 14.18$ & $0.17 \pm 0.17$ \\
\hline III & $56.25 \pm 5.86$ & $35.50 \pm 04.21$ & $0.00 \pm 0.00$ & $08.25 \pm 01.79$ & $0.00 \pm 0.00$ \\
\hline
\end{tabular} $\begin{aligned} & \text { S.E.M = Standard Error of the Mean (8 animals / group) } \\
& \text { EAC cells - Ehrlich ascitic carcinoma cells, N - Neutrophils, E - Eosinophils, B - Basophiles, L - Lymphocytes, M - } \\
& \text { Monocytes }\end{aligned}$


in myometrial and leiomyomal cells, in dosedependent manner, consequently inhibiting the estrogen synthesis in tumor cells (Lee et al. 2004).

The toxicity of EE on mice was evaluated in a previous study (Sevastre et al. 2014). All the mice subjected to toxicity test remained alive until the end of the study; therefore, LD 50 could not be established. Gross necropsy and histopathology did not reveal abnormalities in any of the organs. Serum biochemistry and complete blood count showed normal values, therefore we concluded that findings suggest that the EE extract is safe even at very high dose (Sevastre et al. 2014).

The EAC is a transplantable tumor of epithelial origin descended from a murine mammary gland adenocarcinoma. Not only it provides an appropriate model to assess the antiproliferative effects of various compounds, but it is also suitable to investigate the side effects of tumor growth and the interaction between tumor cells and the immune system. The Ehrlich tumor cells development in the abdominal cavity results in accumulating of abundant exudate, rich in tumor cells. Mediators produced by tumor cells are responsible for the increased vascular permeability, which leads to the extensive red blood cells leakage into abdominal cavity, resulting in anemia. This is widely accepted as malignant consequence of the EAC. Hemorrhage is secondary to extensive extravasations of red blood cells in peritoneal cavity, which leads to degradation of peritoneal capillaries (Mayer, 1966). In our current findings, supported by previous studies performed on Ehrlich ascitic tumor cells, decreased numbers of inflammatory cells were present, even in highly hemorrhagic samples, but they can increase significantly in response to therapy. Furthermore, we proved that the concentration of inflammatory cells in the ascitic fluid is negative correlated to the quantity of ascitic fluid and tumor cell concentration (Sarpataki et al., 2011). The inflammatory cells found in the ascitic fluid seem to provide some protective effect, but the blood leukocytes had no influence on tumor cells development. WBCs reach elevated concentrations in response to tumor cell proliferation, more likely because of having been stimulated by inflammatory cytokines produced by tumor cells. However, circulating white blood cells seem to provide little protection, because they are in negative correlation with the inflammatory cell population in ascitic fluid.

The current data, as described above, shows that EE extract significantly $(\mathrm{p}<0.05)$ reduced ascitic fluid accumulation and inhibited tumor cell proliferation in a dose-dependent manner. The anticancer mechanism is likely to be provided by more than one mechanism. The EE extract clearly reduced the intensity of ascitic hemorrhage, but whether it was a specific protective effect on the vascular walls or a simple side effect of reduced proliferation, remains to be established. The

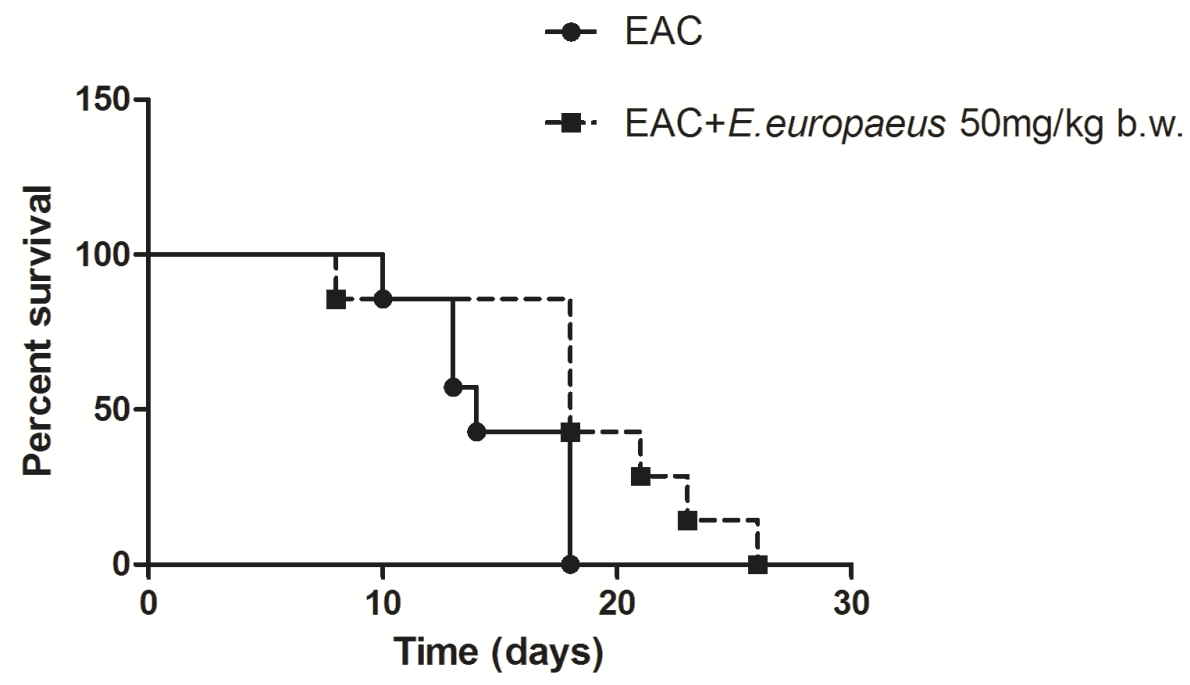

Fig. 3. Effects of Euonymus europaeus $50 \mathrm{mg} / \mathrm{kg}$ on survival curves of EAC bearing mice. (mean \pm SEM) $(\mathrm{p}<0.05)(8$ animals / group) 
antiproliferative effect of EE was undoubtedly proven, by reduced body weight gain, by decreased ascitic fluid volume and decreased viable tumor cells. Furthermore, the survival experiment proved that EE therapy was able to improve the survival rate in a significant manner. The antiproliferative effect may be due to the induction of apoptosis or cell cycle arrest, but the enhancement of local immune activity cannot be excluded either. As support to the last hypothesis, there is an elevated number of neutrophils and lymphocytes found in the ascitic fluid as a response to therapy.

In the present study, we proved that the EE alcoholic extract inhibits the development of Ehrlich tumor cells on mice model. The inhibition was positively correlated with the amplitude of the local inflammatory response in the peritoneal fluid and negatively correlated with the systemic inflammatory response, which suggest that the enhancement of cell-mediated immunity might be part of the tumoricidal properties of EE.

Acknowledgments. This study was supported by an internal research grant of the University of Agricultural Science and Veterinary Medicine Cluj Napoca.

Declaration of interests: The authors report no declaration of interest.

\section{REFERENCES}

1. Agostino M, Velkov T, Dingjan T, Williams SJ, Yuriev E, Ramsland PA (2015). The carbohydrate-binding promiscuity of Euonymus europaeus lectin is predicted to involve a single binding site. Glycobiology 25:101-14.

2. Cha BY, Park CJ, Lee DG, Lee YC, Kim DW, Kim JD, Seo WG, Moon SK, Kim CH (2003). Inhibitory effect of methanol extract from Euonymus alatus on matrix metalloproteinase-9. J Ethnopharmacol 85:163-7.

3. Chabner BA, Roberts TG Jr (2005). Chemotherapy and the war on cancer. Nat Rev Cancer 5: 65-72.

4. Chung TW, Moon SK, Chang YC, Ko JH, Lee YC, Cho G, Kim SH, Kim JG, Kim CH (2004). Novel and therapeutic effect of caffeic acid and caffeic acid phenyl ester on hepatocarcinoma cells: complete regression of hepatoma growth and metastasis by dual mechanism. FASEB J 18: 1670-81.

5. Descoins C Jr, Bazzocchi IL, Ravelo AG (2002). New sesquiterpenes from Euonymus europaeus (Celastraceae). Chem Pharm Bull (Tokyo) 50:199-202.
6. Jin UH, Lee JY, Kang SK, Kim JK, Park WH, Kim JG, Moon SK, Kim CH, Jin UH (2005). L phenolic compound, 5-caffeoylquinic acid (chlorogenic acid), is a new type and strong matrix metalloproteinase-9 inhibitor: isolation and identification from methanol extract of Euonymus alatus. Life Sci 77:2760-9.

7. Kim CH, Kim DI, Kwon CN, Kang SK, Jin UH, Suh SJ, Lee TK, Lee IS (2006). Euonymus alatus (Thunb.) Sieb induces apoptosis via mitochondrial pathway as prooxidant in human uterine leiomyomal smooth muscle cells. Int J Gynecol Cancer 16:843-8.

8. Lee TK, Kim DI, Han JY, Kim CH (2004). Inhibitory effects of Scutellaria barbata D. Don. and Euonymus alatus Sieb. on aromatase activity of human leiomyomal cells. Immunopharmacol Immunotoxicol 26:315-27.

9. Mayer KD (1966). The pathogenicity of the Ehrlich ascites tumour. Br J Exp Pathol 47:537-44.

10. Park WH, Kim SH, Kim CH (2005). A new matrix metalloproteinase-9 inhibitor 3,4-dihydroxycinnamic acid (caffeic acid) from methanol extract of Euonymus alatus: isolation and structure determination. Toxicology 207:383-90.

11. Sárpataki O, Sevastre B, Olah NK, Hanganu D, Taulescu M, Mănălăchioae R, Cătoi C, Marcus I (2011). Antitumor effects of Viscum album L. on Ehrlich ascites carcinoma in vivo. Bulletin UASVM, Veterinary Medicine 68:320-7.

12. Seo UK, Lee YJ, Kim JK, Cha BY, Kim DW, Nam KS, Kim CH (2005). Large-scale and effective screening of Korean medicinal plants for inhibitory activity on matrix metalloproteinase-9. Ethnopharmacol 97:101-06.

13. Sevastre B, Sarpataki O, Olah NK, Stan RL, Taulescu M, Marcus I, Catoi C (2014). Anti-tumor effect of Euonymus europaeus on Ehrlich tumor cells in vivo. Farmacia 62(5):907-17.

14. Teneberg S, Alsen B, Angstrom J, Winter HC, Goldstein IJ (2003). Studies on Gala3-binding proteins: comparison of the glycosphingolipid binding specificities of Marasmius oreades lectin and Euonymus europaeus lectin. Glycobiology 13:479-86.

15. Jain NC (1993). Essentials of veterinary hematology. Lea \& Febiger, Philadelphia, 54-71.

16. Xu R (2015). Traditional Chinese medicine used for promoting blood circulation and treating blood cancer includes Vaccaria, ginseng, kiwi root, snake slough, jade powder, Solanum lyratum, Acanthus ilicifolius, Euonymus alatus and rose. Patent Number CN104758464-A.

17. *** European Pharmacopoeia, ed. 8, EDQM, 2012.

18. *** German Homeopathic Pharmacopoeia. Evonymus europaea monograph (2010). Deutsche Apotheke Verlag, Stuttgart.

19. *** German Homeopathic Pharmacopoeia (2013). Deutsche Apotheke Verlag, Stuttgart.

20. *** Phytolab HPLC method for determination of evodiamine (2014). 